\title{
Present status and fish seed production of the hatcheries of six upazilas of Rajshahi District
}

\author{
Abdus Salam Bhuiyan, Sarmin Akther and Naima Aktar \\ Department of Zoology, University of Rajshahi, Rajshahi-6205, Bangladesh
}

\begin{abstract}
An investigation was conducted during the period from March to December, 2009 to know the status and fish seed production of the hatcheries of six upazilas of Rajshahi district. All the hatcheries were established during 1968 to 2003 . The occupations of the hatchery owners are hatchery business and others. Training status of the hatchery owners shows that in maximum cases they had no training and other cases had short term training, consulting with UFO etc. Funding source was self and loan, land ownership was own and lease. Fish disease occurs seldomly. The area of hatchery buildings ranged from 5 to 33 decimals. The water carrying capacity of overhead tanks ranged from 9091.90 to 409135.5 liter. The volume of each cistern ranged from $1.73 \mathrm{~m}^{3}$ to $3.93 \mathrm{~m}^{3}$. The volume of circular breeding and hatching tanks, varied from 2.48 $\mathrm{m}^{3}$ to $4.02 \mathrm{~m}^{3}$ and $1.72 \mathrm{~m}^{3}$ to $3.14 \mathrm{~m}^{3}$. The volume of each incubation tank (bottle) ranged from $1.52 \mathrm{~m}^{3}$ to 1.08 $\mathrm{m}^{3}$. The number of permanent workers ranged from 2 to 6 in all seasons. Six native species (rui, catla, mrigel, calibaush, bata and gonia) and six exotic species (silvercarp, bighead carp, grass carp, common carp, Thai pangus and Thai puti) were used for seed production. Two types of hormonal injections, such as Pituitary Gland (PG) and Human Chorionic Gonadotropin (HCG) were used for this purpose. Average fry production were for rui, $140.38 \pm 127.02 \mathrm{~kg}$, catla, $37.25 \pm 29.24 \mathrm{~kg}$, mrigel, $105.63 \pm 54.84 \mathrm{~kg}$, calibaush, $13.50 \pm 5.75 \mathrm{~kg}$, gonia, $32 \pm 0$ $\mathrm{kg}$, bata, $166 \pm 113.27 \mathrm{~kg}$, silvercarp, $132.38 \pm 96.32 \mathrm{~kg}$, bighead carp, $120.71 \pm 116.62 \mathrm{~kg}$, grass carp, $31 \pm$ $11.53 \mathrm{~kg}$, common carp, $140.83 \pm 93.83 \mathrm{~kg}$, Thai pangus, $10 \pm 0 \mathrm{~kg}$, Thai puti, $42.33 \pm 33.71 \mathrm{~kg}$ was recorded in some surveyed private hatcheries. The total fry production in some surveyed hatcheries ranged from 85 to 1698 $\mathrm{kg}$ with an average of $662.75 \pm 513.83 \mathrm{~kg}$.
\end{abstract}

Keywords: Hatchery, fish seed production, induced breeding, inducing agents, fish fry.

\section{Introduction}

Bangladesh is an agrarian country. Fisheries is one of the major components of agricultural activities and plays a vital role in nutrition, employment, income generation and foreign exchange earning. The availability of fish seed is an essential prerequisite for fish culture. The main sources of fish seeds in Bangladesh are spawn produced in government and private hatcheries, and some collected from rivers. In 2007-2008, the number of government fish hatcheries or fry production farms were 112. In 20072008 , the number of private fish hatcheries were 873 . Rajshahi is one of the richest district of Bangladesh in respect of its vast, diverse and unique fisheries resources in the form of physical, biological and others. Rajshahi district consists of 9 upazilas which are Paba, Puthia, Mohonpur, Durgapur, Bagmara, Bagha, Godagari, Tanore and Charghat. In Rajshahi district the number of public hatcheries are two and private hatcheries are thirty. But now few private hatcheries are closed. Nowadays due to the degradation of ecological balance, natural resource of fish seeds are destroyed. So, hatchery is now the main source of fish seed production. The term "Hatchery" is considered in broadest sense as a facility where fish fry and fingerlings suitable for stocking in growth ponds are produced in artificial manner by the process of induced breeding technique. Induced breeding is a technique whereby ripe brood fishes are stimulated by treating them with inducing agents to breed in captivity. The stimulation promotes a timely release of eggs and milt from ripe breeders. It is now used as a widely accepted means of artificial propagation to overcome constraints in fish seed supply particularly for species that do not breed in captivity.

\section{Materials and Methods}

This study deals with twenty two hatcheries, their status and production rate of fish seeds of six upazilas (Paba, Puthia, Mohonpur, Durgapur, Bagmara and Bagha) of Rajshahi district during the period of March to December, 2009. The study was survey based, survey method was used to collect data. For data collection, a reasonable size of sample was considered. Firstly, a survey schedule was prepared and the data of status and seed production rate of the hatcheries were collected by survey and interview methods. The collected data were checked, summarized and scrutinized carefully. Some data were collected by observation and picture methods also. Data were also collected from district and upazila fishery offices. Data were analyzed and presented for statistical justification

\section{Results and Discussion}

The two public and twenty private hatcheries were scattered at Paba, Puthia, Mohonpur, Durgapur, Bagmara and Bagha upazilas of Rajshahi district. All the hatcheries were established during 1968 to 2003. The list of the surveyed hatcheries, their addresses, their establishment years and total fry production of some hatcheries are shown in the Table-1. 
Table 1. Hatcheries, sites, establishment year and total fry production of some hatcheries (*Public hatcheries).

\begin{tabular}{|c|c|c|c|c|}
\hline SI. No. & Name of the hatchery & Upazila & $\begin{array}{c}\text { Year of } \\
\text { establishment }\end{array}$ & $\begin{array}{l}\text { Total fry production }(\mathrm{kg}) \\
\text { (Recorded in 2009) }\end{array}$ \\
\hline *1 & Rajshahi Matshow Beej Utpadon Khamar & Paba, & 1968 & 85 \\
\hline 2 & Mashud Matshow Hatchery & Paba, & 1993 & 1000 \\
\hline 3 & Anand Matshow Hatchery & Paba, & 1997 & 600 \\
\hline 4 & Sarkar Matshow Hatchery & Paba, & 1994 & - \\
\hline *5 & Puthia Matshow Beej Utpadon Khamar & Puthia & 1969 & 107 \\
\hline 6 & Mullata Hatchery & Puthia & 1993 & - \\
\hline 7 & Shuvo-Irin Matshow Prokolpo Hatchery & Puthia & 1994 & 1260 \\
\hline 8 & Atique Matshow Hatchery & Puthia & 2003 & - \\
\hline 9 & Duivai Sonali Matshow Hatchery & Mohonpur & 1997 & 680 \\
\hline 10 & Faisal Agro Fisheries & Mohonpur & 1993 & 710 \\
\hline 11 & Merina Matshow Hatchery & Bagmara & 1995 & - \\
\hline 12 & Bani Matshow Hatchery & Bagmara & 1997 & - \\
\hline 13 & Bahi Bhai Matshow Hatchery & Bagmara & 1991 & 1043 \\
\hline 14 & Monika Hatchery & Bagmara & 1989 & 1698 \\
\hline 15 & Manchur Matshow Hatchery & Durgapur & 1993 & - \\
\hline 16 & Amagachi Carp Hatchery & Durgapur & 1992 & - \\
\hline 17 & Bhai Bon Matshow Hatchery & Durgapur & 1992 & - \\
\hline 18 & Inni Matshow Prozonon Khamar & Durgapur & 1993 & 202 \\
\hline 19 & Ibne Salam Matshow Hatchery & Durgapur & 1994 & 98 \\
\hline 20 & Zahid Matshow Hatchery & Durgapur & 1994 & - \\
\hline 21 & Sarker Matshow Hatchery & Durgapur & 1993 & - \\
\hline \multirow[t]{3}{*}{22} & Seba Agro Company Ltd. & Bagha & 2002 & 470 \\
\hline & Minimum & 85.00 & Total & 7953 \\
\hline & Maximum & 1698.00 & Mean \pm SD & $662.75 \pm 513.83$ \\
\hline
\end{tabular}

Occupation, training status, fund source, land category ownership and occurrence of fish diseases in the hatcheries: Among the surveyed hatcheries, $42.87 \%$ owners depended on hatchery business only, $20.80 \%$, hatchery business and service, $30.58 \%$, hatchery business and agriculture and $5.75 \%$, depended on hatchery business and others.

About $38.16 \%$ hatchery owners had no institutional training, $19.56 \%$ had short term training, $15 \%$ consulting with UFO and $27.28 \%$ gathered knowledge through personal communications.

Regarding source of fund, $40.62 \%$ hatchery owners had their fund, from own sources; $29 \%$ got fund from own source, loan from relatives, friends and banks, $21.29 \%$, owners got fund; from banks, own source and NGO's and $9.09 \%$ got fund from Govt.

It was found that $47.62 \%$ hatchery owners used their own land and leased land; $52.38 \%$ of them used their own land.
During the investigation it was observed that, there were seldom attack of fish disease in $70.76 \%$ of hatcheries and the rest $29.24 \%$ of the hatcheries were free from diseases.

Physical status of the hatcheries: Hatcheries are formed by different small units. Different parameters of the surveyed hatcheries are as follows-

The area of 22 hatchery building ranged from 5 to 33 decimals. The water carrying capacity of the overhead tanks ranged from 9091.90 to 409135.5 liter. The number of cisterns varied from 3 to 10 and volume of each cistern ranged from $1.73 \mathrm{~m}^{3}$ to $3.93 \mathrm{~m}^{3}$. The number of circular breeding and hatching tanks in different hatcheries varied from 1 to 5 and 1 to 3 and their volume varied from 2.48 $\mathrm{m}^{3}$ to $4.02 \mathrm{~m}^{3}$ and $1.72 \mathrm{~m}^{3}$ to $3.14 \mathrm{~m}^{3}$. The number of incubation tanks (bottles) ranged from 3 to 13 and volume of each bottle ranged from $0.52 \mathrm{~m}^{3}$ to $1.08 \mathrm{~m}^{3}$. The number of permanent workers ranged form 2 to 6 in all seasons of each hatchery. 


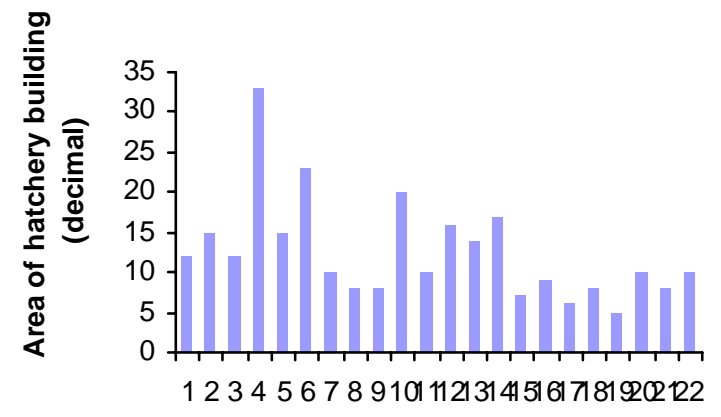

Sl. no. of hatcheries

Fig. 1. Area of hatchery building of different hatcheries.

Circular breeding tank Circular hatching tank

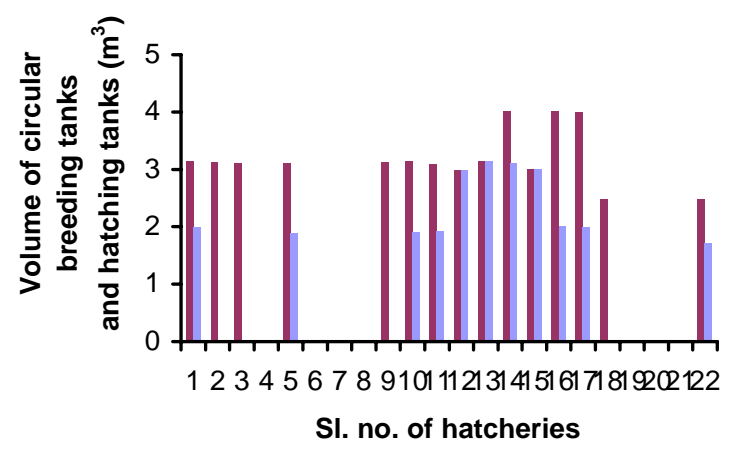

Fig. 2. Volume of circular breeding and hatching tanks of different hatcheries.

Biological status: Fish species: It was observed that, 12 fishes were used for hatching purpose, among them 6 were native and 6 fish species were exotic. Native species were, rui (Labeo rohita), catla (Catla catla), mrigel (Cirrhina mrigala), calibaush (Labeo calbasu), bata (Labeo bata), gonia (Labeo gonius) and exotic species were; silver carp (Hypophthalmicthys molitrix), bighead carp (Aristichthys nobilis), grass carp (Ctenopharyngodon idella), common carp (Cyprinus carpio), Thai pangus (Pangasius sutchi) and Thai puti (Puntius gonionotus).

Induced breeding: The observed hatchery owners used mainly two types of hormones for induced breeding. Such as Pituitary Gland (PG) and Human Chorionic Gonadotropin (HCG).

Fish seed production: The production rate of fish seeds depend on weather, water quality, brood fish selection, proper dose of hormonal injection and expart hatchery operations.

Total production of fry of some surveyed hatcheries and species wise fry production of some surveyed private hatcheries are shown in Table-1 and Table-2 For producing fish seeds, 873 hatcheries have been established in Bangladesh (DoF, 2009). At present, there are two public and about thirty private hatcheries in Rajshahi district. All the hatcheries were established during 1968 to 2003. (Mohsin, et al., 2010). According to Hasan and Ahmed, (2002), three Indian, major carps (rui, catla and mrigel) and three exotic carps (silver, grass and common carps) were the dominant fish species cultured in most hatcheries of Bangladesh.

Table 2. Showing the annual production capacity $(\mathrm{kg})$ and the species wise fry production $(\mathrm{kg})$ of some of the surveyed private hatcheries (informations of other hatcheries were not available).

\begin{tabular}{|c|c|c|c|c|c|c|c|c|c|c|c|c|c|}
\hline \multirow{2}{*}{$\begin{array}{l}\text { Sl. no. of } \\
\text { hatchery }\end{array}$} & \multirow{2}{*}{$\begin{array}{c}\text { Annual } \\
\text { production } \\
\text { capacity }\end{array}$} & \multicolumn{6}{|c|}{ Fry production of native species } & \multicolumn{6}{|c|}{ Fry production of exotic species } \\
\hline & & Rui & Catla & Mrigel & Calibaush & Gonia & Bata & Silvercarp & $\begin{array}{l}\text { Bighead } \\
\text { carp }\end{array}$ & $\begin{array}{l}\text { Grass } \\
\text { carp }\end{array}$ & Commoncarp & $\begin{array}{c}\text { Thai } \\
\text { Pangus }\end{array}$ & $\begin{array}{l}\text { Thai } \\
\text { Puti }\end{array}$ \\
\hline 7 & 2000 & 190 & 55 & 185 & - & - & 290 & 225 & 150 & 40 & 45 & - & 80 \\
\hline 9 & 1200 & 85 & 35 & 90 & - & - & 40 & 60 & 90 & - & 280 & - & - \\
\hline 10 & 1800 & 100 & 30 & 130 & 10 & - & 90 & 70 & 60 & - & 220 & - & - \\
\hline 13 & 1100 & 175 & 15 & 155 & - & - & 130 & 260 & 155 & 18 & 110 & 10 & 15 \\
\hline 14 & 1800 & 420 & 28 & 134 & 12 & 32 & 280 & 232 & 353 & 35 & 140 & - & 32 \\
\hline 18 & 500 & 40 & 30 & 45 & 22 & - & - & 40 & 25 & - & - & - & - \\
\hline 19 & 350 & 23 & 5 & 26 & 10 & - & - & 22 & 12 & - & - & - & - \\
\hline 22 & 600 & 90 & 100 & 80 & - & - & - & 150 & - & - & 50 & - & - \\
\hline Total & 9350 & 1123 & 298 & 845 & 54 & 32 & 830 & 1059 & 845 & 93 & 845 & 10 & 127 \\
\hline Minimum & 350 & 23 & 5 & 26 & 10 & 32 & 40 & 22 & 12 & 18 & 45 & 10 & 15 \\
\hline Maximum & 2000 & 420 & 100 & 185 & 22 & 32 & 290 & 260 & 353 & 40 & 280 & 10 & 80 \\
\hline $\begin{array}{l}\text { Mean } \\
\pm \text { SD }\end{array}$ & $\begin{array}{l}1168.75 \\
\pm 647.49\end{array}$ & $\begin{array}{c}140.38 \\
\pm 127.02\end{array}$ & $\begin{array}{c}37.25 \\
\pm 29.24\end{array}$ & $\begin{array}{l}105.63 \\
\pm 54.84\end{array}$ & $\begin{array}{l}13.50 \\
\pm 5.75\end{array}$ & $\begin{array}{l}32 \\
\pm 0\end{array}$ & $\begin{array}{c}166 \\
\pm 13.27\end{array}$ & $\begin{array}{l}132.38 \\
\pm 96.32\end{array}$ & $\begin{array}{c}120.71 \\
\pm 116.62\end{array}$ & $\begin{array}{c}31 \\
\pm 11.53 \\
\end{array}$ & $\begin{array}{l}140.83 \\
\pm 93.83\end{array}$ & $\begin{array}{l}10 \\
\pm 0\end{array}$ & $\begin{array}{r}42.33 \\
\pm 33.71\end{array}$ \\
\hline
\end{tabular}


More or less similar observation was found in this study. The fish seeds are produced in the hatcheries by the process of induced breeding through inducing agents. Mainly two types of inducing agents (PG and $H C G$ ) were used in the surveyed hatcheries. Fontenel, 1955; Atz and Pickford, 1959; Tang et al., 1963; Ali, 1967; Chaudhuri, 1976; Bhowmick, et al., 1978; Jhingran and Pullin, 1985; Mirza, et al., 1993; Verdia, 1994; Alam and Bhuiyan, 1999; Bhiyan et al., 2007; Bhuiyan, et al., 2008 etc. also adopted the similar practice. From the investigational study, it was observed that the production of fish seeds are not sufficient than production capacity. More or less similar observation was found in the study of Islam, et al., 2002; Hossain and Siddique, 2009. The annual production capacity $(\mathrm{Kg})$ of some of the surveyed private hatcheries ranged from minimum 350 to maximum $2000 \mathrm{~kg}$. The total production of fry of some surveyed hatcheries were lowest 85 to highest $1698 \mathrm{~kg}$

Apart from some adverse socioeconomic and other impacts, fish hatcheries contribute a remarkable part of inland fish production in Bangladesh. Emphasis should be given on expansion of hatchery facilities to supply high quality fish seeds required to support aquaculture development More future works are necessary on different aspects of fish seed production. The government and NGOs should provide all modern facilities in connection with the quality fish seeds production in Bangladesh. The present work gives an account of the fish seed production of the hatcheries of Rajshahi district

\section{.Acknowledgement}

The authors are thankful to Mr. M I Golder, DFO of Rajshahi for extending his cordial cooperation. The authors are also grateful to the owners, operators and staffs of the surveyed hatcheries to supply data and information related to the hatcheries.

\section{References}

Alam, M.M. \& Bhuiyan, A.S. 1999. Determination of the optimum PG dose for induced spawning of Labco rohita (Hamilton, 1822). Univ. J. Zool. Rajshahi Univ. 18: 103108.

Ali, M.H. 1967. Induced breeding of major carps in ponds by pituitary hormone injection, Agric. Inform. Serv. Dhaka.

Atz, J.W. \& Pickford, G.E. 1959. The use of pituitary hormones in fish culture. Endeavour. 18(71): 125-129.
Bhowmick, R.M., Kowtal, G.V., Jana, R.K. \& Gupta, S.D. 1978. Large scale production of the seed of Catla catla (Ham.) by hypophysation J. Inland. Fish. Soc. India. 10: 3.

Bhuiyan, A.S. Islam, M.K. \& Tanzeena, Z. 2007. Induced spawning of Puntius gonionotus (Bleeker). Bangladesh J. Zool. 35(2): 245-249.

Bhuiyan, A.S., Musa, A.S.M. \& Islam, M.K. 2008. Hatchery management in Bangladesh. Aquaculture Asia Magazine, Bangkok: 20-23.

Chaudhuri, H. 1976. Uses of hormones in induced spawning of carps, J. Fish. Res. Board. Canada. 33: 940-947.

DoF, 2009. Fishery wealth of Bangladesh(in Bengali). Jatio matshow shaptaho, 2009 (Shonkolon), Department of Fisheries, Ministry of Fisheries and Livestock, Govt. of People's Republic of Bangladesh. 105-111 pp.

Fontenel, O. 1955. Injecting pituitary (hypophyseal) hormones into fish to induce spawning. Prog. Fish. Cult. 17(2): 71-75.

Hasan, M.R. \& Ahmed, G.U. 2002. Issues in carp hatcheries and nurseries in Bangladesh, with special reference to health management. FAO Fisheries tech, paper, Dept. Aquaculture. Bangladesh Agril. Univ. Mymensingh 2002 (406) : 147-164.

Hossain, D.G. \& Siddiqui., A.B. 2009. Present status of hatcheries and fish production of Rajshahi. BSS, Rajshahi, Bangladesh. 2 p.

Islam, M.N., Chowdhury, M.F.R. and Mohsin, A.B.M. 2002. Role of hatchery in the fish culture development of Rajshahi district in Bangladesh. Univ. J. Zool. Rajshahi Univ. 21: 73-76.

Jhingran, V.G. \& Pullin, R.S.V. 1985. A hatchery manual for the common Chinese and Indian major carps. Centre for living Aquatic Resource Management, Manila, Philippines, $166 \mathrm{pp}$.

Mirza, Z.S., Naik, I.U. \& Bhatti, M.Z. 1993. Induced spawning of Indian major carps using carp pituitary homogenate and human chorionic gonadotropin in the Punjab (Pakistan). Proc. Pak. Cong. Zool. 12: 423-428.

Mohsin, A.B.M., Jahan, S.N., Islam, M.M., \& Hossain, M.A. 2010. Present status and management system of carp hatcheries of Rajshahi district. Abstract of seminar on fisheries activities in northern Bangladesh: sustainable livelihood and climate change aspects. Department of Fisheries University of Rajshahi P. 23.

Tang, Y.A., Hwang, Y.W. \& Liu, C.K. 1963. Preliminary report on injection of pituitary hormone to induced spawning of Chinese carps. Occ. Pap. Indo-Pacif. Fish Coun. 14: 71.

Verdia, H.K. 1994. Advancement of maturity with HCG in Indian major carps. J. Aquat. Biol. Fish. 1(1): 1922. 